\title{
Performance of Frogeye Leaf Spot-Resistant and -Susceptible Near-Isolines of Soybean
}

\author{
M. A. R. Mian and H. R. Boerma, Department of Crop and Soil Sciences, University of Georgia, Athens 30602- \\ 7272; D. V. Phillips, Department of Plant Pathology, Georgia Experiment Station, Griffin 30223; M. M. Kenty, \\ American Cyanamid Co., Collierville, TN 38017; G. Shannon, Delta and Pine Land Co., Scott, MS 38772; E. R. \\ Shipe, Department of Crop and Soil Science, Clemson University, Clemson, SC 29634-0359; A. R. Soffes Blount, \\ NFREC, Quincy, FL 32351; and D. B. Weaver, Department of Agronomy, Auburn University, Auburn, AL 36849
}

\begin{abstract}
Mian, M. A. R., Boerma, H. R., Phillips, D. V., Kenty, M. M., Shannon, G., Shipe, E. R., Soffes Blount, A. R., and Weaver, D. B. 1998. Performance of frogeye leaf spot-resistant and -susceptible near-isolines of soybean. Plant Dis. 82:1017-1021.

Frogeye leaf spot (FLS) caused by Cercospora sojina Hara is a disease of soybean (Glycine max (L.) Merr.) that causes significant seed yield losses in warm, humid environments of southeastern United States. The $\operatorname{Rcs}_{3}$ gene in soybean has been reported to condition resistance to all known races of $C$. sojina. The objectives of this study were to determine the effectiveness of $R s_{3}$ in limiting seed yield loss due to FLS and to compare the seed yield of the resistant and susceptible near-isolines (NILs) in the absence of significant FLS disease. Four pairs of NILs-

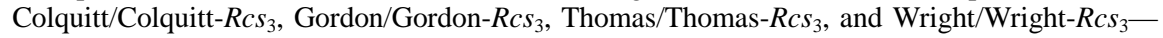
were evaluated in 23 field experiments in Alabama, Florida, Georgia, Louisiana, Mississippi, and South Carolina during 1992 to 1994. The amount of damage to susceptible soybean caused by FLS was dependent on the specific environment. All four of the $R c s_{3}$ NILs were resistant to the prevalent races of FLS in all environments. In the absence of significant FLS disease, each of the $R c s_{3}$ NILs was at least equal to the respective susceptible line in its seed yield. In the presence of FLS infestation, the susceptible lines suffered significant seed yield loss (up to $31 \%$ ) compared to their $R_{c s_{3}}$ NILs. The effect of FLS on seed yield was dependent on cumulative disease severity over the growing season. Thus, the area under disease progress curve was more useful than percent of leaf area infected at the end of the growing season (R7 stage of development) in explaining the seed yield loss due to FLS.
\end{abstract}

Additional keywords: backcrossing, Davis

Frogeye leaf spot (FLS) caused by Cercospora sojina Hara is primarily a foliar disease of soybean (Glycine max (L.) Merr.), even though seeds, pods, and stems can also be infected. The incidence of FLS in soybean is dependent on the growing conditions (1) and the disease is favored by warm, humid conditions (18). The yield loss from FLS is mainly the result of reduced photosynthetic area and premature defoliation (1).

Frogeye leaf spot of soybean was first reported in the United States in 1924 (11). By the late 1940s, it was a serious disease of soybean in parts of the Midwest (2). Use of resistant cultivars greatly reduced the

Corresponding author: H. R. Boerma

E-mail: rboerma@arches.uga.edu

This research was supported in part by state and Hatch funds allocated to the Georgia Agricultural Experiment Station and by a grant from the Georgia Commodity Commission for Soybeans and the United Soybean Board.

Accepted for publication 8 June 1998.

Publication no. D-1998-0710-02R

(C) 1998 The American Phytopathological Society incidence of this disease until the late 1950 s, with the appearance of $C$. sojina race 2 (3). In the mid $1960 \mathrm{~s}, C$. sojina races 3 and 4 were found in North Carolina (17). Race 5 of $C$. sojina was found in 1978 (13). Many elite cultivars were susceptible to this race, but resistant cultivars were also available.

Resistance to races 1 and 2 is conditioned by genes $\operatorname{Rcs}_{1}(2,15)$ and $R c s_{2}(16)$, respectively. The inheritance of resistance to race 3 and 4 has not been reported (4). A single dominant gene, $R c_{3}$, in cultivar Davis was responsible for resistance to race 5 (4). The $R c_{3}$ gene is believed to condition resistance to all known races of C. sojina in the United States (14). Different dominant genes for resistance to race 5 in "Ransom," "Stonewall," and "Lee" were reported in 1993 and each of these genes was non-allelic to $\operatorname{Rcs}_{3}$ and to each other (12).

Frogeye leaf spot causes significant yield losses in warm, humid environments of the southeastern United States. Up to $21 \%$ yield loss of soybean cultivar Clark due to FLS was reported in Indiana (9). A comparison of FLS-resistant and -susceptible soybean breeding lines in the United States Department of Agriculture Uniform
Tests indicated yield losses varying from $10 \%$ at Quincy, Florida (8) to $30 \%$ at Tallassee, Alabama (7). Greater than 60\% yield loss due to FLS has been reported in the tropical environment of Nigeria $(5,19)$.

Four Maturity Group VII soybean cultivars and their $\operatorname{Rss}_{3}$ NILs were evaluated at multiple locations in the southeastern United States over 3 years in order to (i) determine the effectiveness of the $\mathrm{Rcs}_{3}$ gene in limiting seed yield loss due to FLS and (ii) compare the seed yield of the resistant and susceptible NIL pairs in the absence of significant FLS disease.

\section{MATERIALS AND METHODS}

The genotypes included in this study were the NIL pairs of Colquitt/Colquitt$R c_{3}$, Gordon/Gordon- $R c_{3}$, Thomas/Thomas$R c s_{3}$, and Wright/Wright- $R c s_{3}$. The $R c s_{3}$ NILs were developed by backcrossing the $\mathrm{Rcs}_{3}$ gene from Davis into Colquitt, Gordon, Thomas, and Wright. The specific parentage of each $\mathrm{Rcs}_{3}$ NIL was Colquitt ${ }^{6}$ $\times$ Davis, Gordon ${ }^{6} \times$ Davis, Thomas ${ }^{6} \times$ Davis, and Wright ${ }^{6} \times$ Davis. In each backcross generation, the $\mathrm{F}_{1}$ plants were inoculated with the BG isolate of $C$. sojina. This isolate was previously shown to detect the $\mathrm{Rcs}_{3}$ gene for resistance to C. sojina. For each recurrent parent, $\mathrm{BC} \mathrm{F}_{2: 3}$ lines were screened in both the greenhouse and field to identify homozygous $\operatorname{Rcs}_{3}$ lines.

The NILs were evaluated from 1992 to 1994 at multiple locations across the southeastern United States. In 1992, the experiments were conducted at Athens and Midville, Georgia. A total of $14 \mathrm{BC} \mathrm{F}_{2: 3}$ lines were evaluated from each recurrent parent along with four entries of each recurrent parent. Based on these data, the $R c s_{3}$ lines most similar in maturity and other agronomic characteristics to their recurrent parent were composited to create Colquitt- $R \mathrm{Cs}_{3}$, Gordon- $R \mathrm{Cs}_{3}$, Thomas- $R c s_{3}$, and Wright- $R \mathrm{Cs}_{3}$.

In 1993, the four pairs of NILs along with donor parent Davis were grown in 11 environments: Athens, Midville, and Plains, Georgia; Clemson and Blackville, South Carolina; Fairhope and Tallassee, Alabama; Stoneville, Mississippi; Morganza, Louisiana; and Quincy (early planted) and Quincy (late planted), Florida. In 1994, there were 10 environments: Athens, Midville, and Plains, Georgia, Clemson, South 
Carolina; Fairhope and Tallassee, Alabama; Stoneville, Mississippi; Morganza, Louisiana; and Quincy (early planted) and Quincy (late planted), Florida.

Typically, these experiments were conducted in four-row plots which were 7 to 8 $\mathrm{m}$ long with $72-$ to $96-\mathrm{cm}$ row spacing. The experimental design for all experiments was a randomized complete block with four replicates, except for the Athens and Midville experiments in 1992, where only two replicates were used.

Data were collected on FLS leaf lesions, plant height, maturity, lodging, and seed yield. The plots were assessed for percent leaf area damaged by FLS at 2-week inter- vals beginning 15 August and continuing until the plants reached R7 stage of development (6). At each sampling date, 10 leaflets were randomly selected from the upper one-third of the canopy. Each leaflet was assessed for percent leaf area damaged by FLS by comparing it to a pictorial leaf lesion evaluation guide. The guide had drawings of leaflets with $0.5,1.0,2.0,4.0$, $8.0,12.0,16.0$, and $20.0 \%$ of leaf area covered with lesions. An arbitrary threshold of 2\% leaf area damaged by FLS was established based on years of observations of the performance of soybean with FLS infestation. If no cultivar at a location had a mean above $2 \%$, the damage was consid-

Table 1. Ratios between the digital image processing measurements and visual estimates made by different observers for leaf area damage at R7 stage of development on four soybean cultivars by frogeye leaf spot in 1993

\begin{tabular}{lccc}
\hline & \multicolumn{3}{c}{ Observer (location) } \\
\cline { 2 - 4 } Cultivar & \#1 (Morganza) & \#2 (Quincy) & \#3 (Tallassee) \\
\hline Colquitt & 0.493 & 0.432 & 1.028 \\
Gordon & 0.480 & 0.547 & 1.044 \\
Thomas & 0.474 & 0.654 & 1.120 \\
Wright & 0.417 & 0.625 & 1.187 \\
\hline
\end{tabular}

Table 2. Mean seed yield of frogeye leaf spot resistant $\left(R c s_{3}\right)$ and susceptible $\left(r c s_{3}\right)$ near-isolines (NILs) of soybean in experiments with frogeye leaf spot damage at R7 stage of development on $<2 \%$ of total leaf area

\begin{tabular}{lccccc}
\hline & & \multicolumn{4}{c}{ Genotypes $(\mathbf{m g} / \mathbf{h a})$} \\
\cline { 3 - 6 } Year & NIL & Colquitt & Gordon & Thomas & Wright \\
\hline $1992^{\mathrm{a}}$ & $r c s_{3}$ & $2.40^{* * \mathrm{~b}}$ & $3.08^{* *}$ & $3.02^{* *}$ & $1.85^{* *}$ \\
& $R c s_{3}$ & 2.51 & 3.29 & 3.27 & 2.12 \\
1993 & $r c s_{3}$ & $2.46^{\mathrm{NS}}$ & $2.40^{\mathrm{NS}}$ & $2.42^{\mathrm{NS}}$ & $2.41^{\mathrm{NS}}$ \\
& $R c s_{3}$ & 2.45 & 2.42 & 2.37 & 2.42 \\
1994 & $r c s_{3}$ & $2.44^{* \mathrm{c}}$ & $2.55^{* *}$ & $2.69^{\mathrm{NS}}$ & $2.63^{*}$ \\
& $R c s_{3}$ & 2.98 & 2.82 & 2.69 & 2.83 \\
\hline
\end{tabular}

a 1992 data are the average of two experiments with two replications. 1993 and 1994 data are the averages of eight experiments with four replications

$\mathrm{b} * *, *$, and ${ }^{\mathrm{NS}}$ indicate significant difference at $P \leq 0.01, P \leq 0.05$, and not significant, respectively, based on a single df comparison ( $R c s_{3}$ versus $r c s_{3}$ NILs) $F$ test within each year.

${ }^{c}$ The significance level for this comparison was calculated using the genotype $\times$ environment interaction as the error term. ered to be biologically insignificant, and the FLS data from that environment are not presented in this report.

If the final sampling in 1993 had plots with more than $2 \%$ leaf area damaged, the leaflets used for the final assessments were subjected to digital image processing (DIP). Each leaflet was photographed with a Dadge MTI (Michigan City, IN) Series 68 video camera and the image was recorded on a video tape. The recorded images were captured and digitized with an FG100 capture board (Imaging Technology Inc., Woburn, MA) using Image-Pro software (Media Cybernetics, Silver Spring, MD). The percent of leaf area damaged by FLS was then assessed for each leaflet using Image Measure software (Microscience Inc., Federal Way, WA). The cultivar mean of the DIP assessment at each location was divided by the corresponding visual assessment data to obtain an adjustment factor. Each assessment made by an observer for each cultivar was multiplied by the corresponding adjustment factor for that observer, and both the adjusted and non-adjusted assessments were used to evaluate the effect of FLS on soybean seed yield. The data for Tallassee in 1994 was adjusted using the conversion factors from Tallassee in 1993 (the FLS data at this location were collected by the same observer in both years).

Plant height was measured as the average length of plants from the ground to the terminal bud of the plant at maturity. Lodging rating was recorded at maturity on a scale of 1 (all plants erect) to 5 (all plants prostrate). Maturity was recorded as the number of days after 31 August when $95 \%$ of the pods had reached mature pod color (6). For seed yield, the plots were first end trimmed and then machine harvested. Seed yield was expressed as $\mathrm{Mg} \mathrm{ha}^{-1}$ at $13 \%$ moisture basis. For experiments with significant FLS (lesions on $>2 \%$ of total leaf area), the percent seed yield loss for a sus-

Table 3. Percent yield loss, area under disease progress curve (AUDPC), and adjusted percent leaf area damaged by frogeye leaf spot at R7 stage of development (LAD) for the four environments with $>2 \% \mathrm{LAD}$

\begin{tabular}{|c|c|c|c|c|c|c|c|c|c|c|c|c|}
\hline \multirow[b]{2}{*}{ Near-isolines } & \multicolumn{3}{|c|}{ Morganza, 1993} & \multicolumn{3}{|c|}{ Quincy, 1993} & \multicolumn{3}{|c|}{ Tallassee, 1993} & \multicolumn{3}{|c|}{ Tallassee, 1994} \\
\hline & Yield $^{a}$ & AUDPC $^{\mathbf{a}}$ & $\mathbf{L A D}^{\mathbf{b}}$ & Yield & AUDPC & LAD & Yield & AUDPC & LAD & Yield & AUDPC & LAD \\
\hline \multicolumn{13}{|l|}{ Colquitt } \\
\hline$R_{C s}$ & $4.37 * * \mathrm{c}$ & $\ldots{ }^{d}$ & $\ldots$ & $2.62 * *$ & $\ldots$ & $\ldots$ & $2.95 * *$ & & & $3.22 * *$ & & $\ldots$ \\
\hline$r c s_{3}$ & $3.83(12)$ & 123 & 7.4 & 2.35 (10) & 38 & 3.2 & $2.69(9)$ & 191 & 7.2 & $2.96(9)$ & 22 & 2.7 \\
\hline \multicolumn{13}{|l|}{ Gordon } \\
\hline $\mathrm{RCs}_{3}$ & $3.49 * *$ & & & $3.16^{*}$ & & & $2.62 * *$ & & & $3.02^{\mathrm{NS}}$ & & \\
\hline$r c s_{3}$ & 3.09 (12) & 71 & 4.9 & $3.02(4)$ & 45 & 3.5 & $2.15(18)$ & 196 & 5.2 & 3.02 & 32 & $\ddot{4.2}$ \\
\hline \multicolumn{13}{|l|}{ Thomas } \\
\hline $\mathrm{RCs}_{3}$ & $4.23 *$ & & & $3.02 * *$ & & & $2.96 * *$ & & & $3.09^{\mathrm{NS}}$ & & \\
\hline$r c s_{3}$ & $3.96(6)$ & 87 & 6.4 & 2.35 & 58 & 5.1 & $2.42(18)$ & 316 & 11.2 & 3.09 & 34 & 4.3 \\
\hline \multicolumn{13}{|l|}{ Wright } \\
\hline$R c s_{3}$ & $3.83 * *$ & $\ldots$ & & $2.35^{\mathrm{NS}}$ & $\ldots$ & $\ldots$ & $3.36 * *$ & & & $3.09^{\mathrm{NS}}$ & & $\ldots$ \\
\hline $\mathrm{rCs}_{3}$ & $3.43(14)$ & 96 & 5.5 & 2.28 & 50 & 4.0 & $2.28(31)$ & 288 & 9.5 & 3.16 & 28 & 3.3 \\
\hline Mean & (11) & 94 & 6.1 & (7) & 48 & 4.0 & (19) & 248 & 8.3 & (2) & 29 & 3.6 \\
\hline
\end{tabular}

a Yield in Mg/ha and AUDPC in units. Numbers within parenthesis indicate percent yield loss of the susceptible line compared to its $R c s_{3}$ near-isoline (NIL).

b \% leaf area damaged at the end of the growing season (R7 stage of development).

c **, *, and ${ }^{\mathrm{NS}}$ indicate significant difference at $P \leq 0.01, P \leq 0.05$, and not significant, respectively in a single df comparison (Rcs $s_{3}$ versus $\left.r c s_{3} \mathrm{NILs}\right)$.

d ... indicates that the LAD value for the $R c s_{3}$ NIL was $<2 \%$ and no AUDPC was calculated. 
ceptible line was calculated as: ([seed yield of the $\operatorname{Rcs}_{3}$ NIL - seed yield of the recurrent parent]/seed yield of the $R c s_{3}$ NIL) $\times$ 100.

Data from each environment were analyzed by using the GLM procedure of SAS (SAS Institute, Cary, NC). All data (except FLS data) from each environment with $<2 \%$ of the leaf area damaged by FLS were then combined and analyzed across environments within a year. For combined analysis, replication and environment were considered random effects and genotype was considered a fixed effect. Data were not analyzed across years, because the experiments were not conducted in the same sites every year and the lines that were evaluated were also not the same across years (1992 versus 1993 and 1994).

For environments with FLS lesions on $>2 \%$ of total leaf area, all data (including FLS data) were analyzed as described above. In the temporal analysis of disease progress in susceptible lines in these experiments, area under the disease progress curve (AUDPC) was calculated for each line (10). The percent seed yield loss data were regressed on the percent leaf area damaged at R7 stage of development (LAD) as well as on the AUDPC data using the PROC REG procedure of SAS.

\section{RESULTS AND DISCUSSION}

In 1992, FLS lesions developed on <2\% of the leaf area of the susceptible NILs in both environments (data not shown). Out of the 11 environments in 1993, the susceptible NILs developed lesions on $>2 \%$ of the leaf area in 3 environments: Morganza, Louisiana; Tallassee, Alabama; and Quincy (late planted), Florida. In 1994, 2 of the 10 environments-Morganza, Louisiana and Tallassee, Alabama-were favorable for development of the disease on the susceptible NILs. However at Morganza in 1994, the plants were also damaged by southern stem canker (Diaporthe phaseolorum (Cooke \& Ell.) Sacc. var. meridionalis F. A. Fern). Southern stem canker differentially affected the NILs and this complicated the evaluation of the effect of FLS on seed yield. Thus, we are reporting the FLS data from only four environments: Morganza in 1993, Tallassee in 1993, Quincy in 1993, and Tallassee in 1994. Seed yield data, however, are presented from all experiments except Morganza in 1994.

The ratios between the DIP and the visual assessment made by different observers for leaf area damage at R7 are presented in Table 1. The non-adjusted and adjusted cultivar means for LAD, as well as the respective AUDPC values for all four environments (with $>2 \% \mathrm{LAD}$ ), were regressed on the percent seed yield loss of the four susceptible $\left(r c s_{3}\right)$ NILs (compared to the respective $\mathrm{Rcs}_{3}$ NILs). The relationship between the non-adjusted LAD and percent seed yield loss was not significant; however, there was a significant $(P<0.003)$
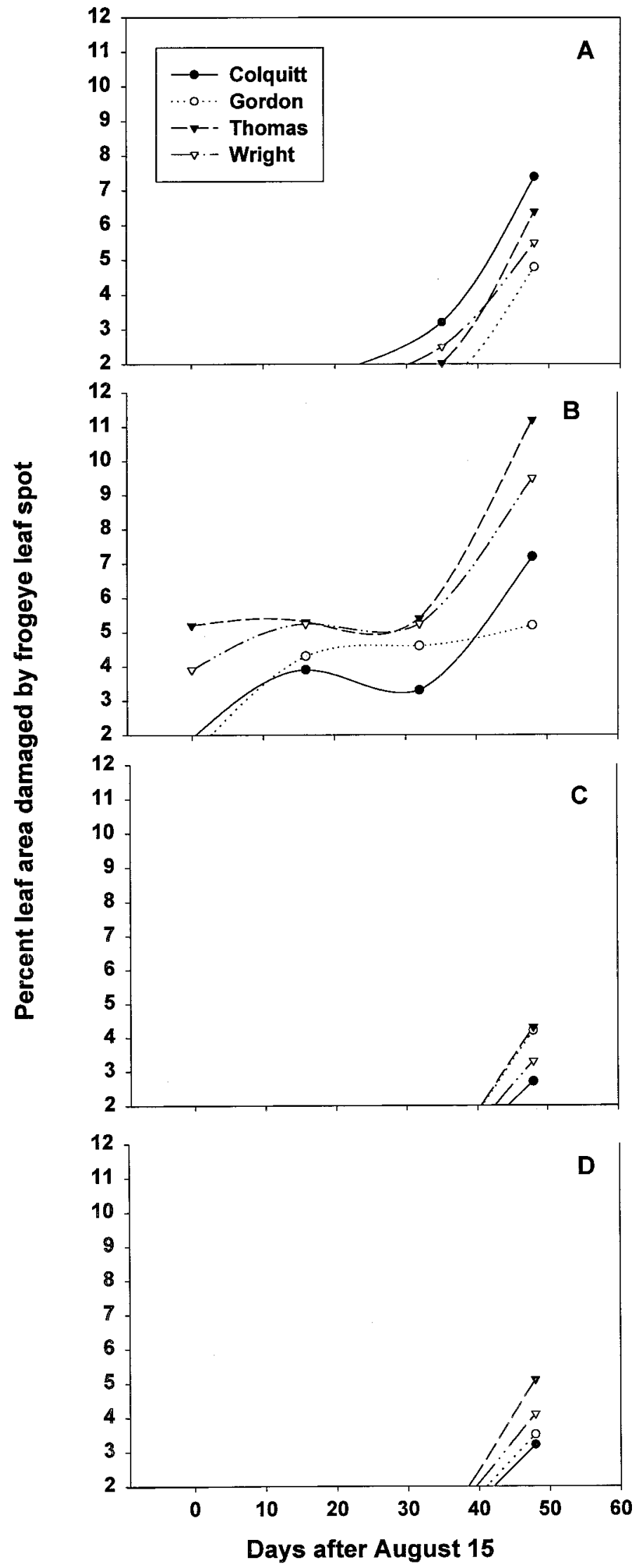

Fig. 1. Development of frogeye leaf spot lesions on four susceptible soybean cultivars (Colquitt, Gordon, Thomas, and Wright) and the area under disease progress curve in the (A) Morganza in 1993, (B) Tallassee in 1993, (C) Tallassee in 1994, and (D) Quincy in 1993 environments. 
positive linear relationship $\left(R^{2}=47 \%\right)$ between the adjusted LAD and seed yield loss. There were also significant positive linear relationships between seed yield loss and both non-adjusted $\left(R^{2}=58 \%\right)$ and adjusted $\left(R^{2}=66 \%\right)$ AUDPC values. The adjusted LAD and adjusted AUDPC, therefore, had more close relationships with counterparts. Thus, in this paper we have presented only the adjusted LAD and the adjusted AUDPC values. oped any appreciable FLS lesions (>2\% seed yield loss than their non-adjusted

None of the resistant $\left(R c s_{3}\right)$ NILs devel-

leaf area infected) in any of the experiments. The FLS damage to the donor parent, Davis, was also limited to $<2 \%$ of its total leaf area in all experiments in 1993 and 1994. It is typical for the $R c_{3}$ gene to allow limited lesion development with heavy $C$. sojina infection under favorable conditions for FLS disease development. All four of the isolines carrying the $R c s_{3}$ allele were, therefore, considered resistant to the prevalent races of FLS in these environments. The development of FLS in only 5 of the 23 experiments conducted over 3 years indicates that severity of FLS was

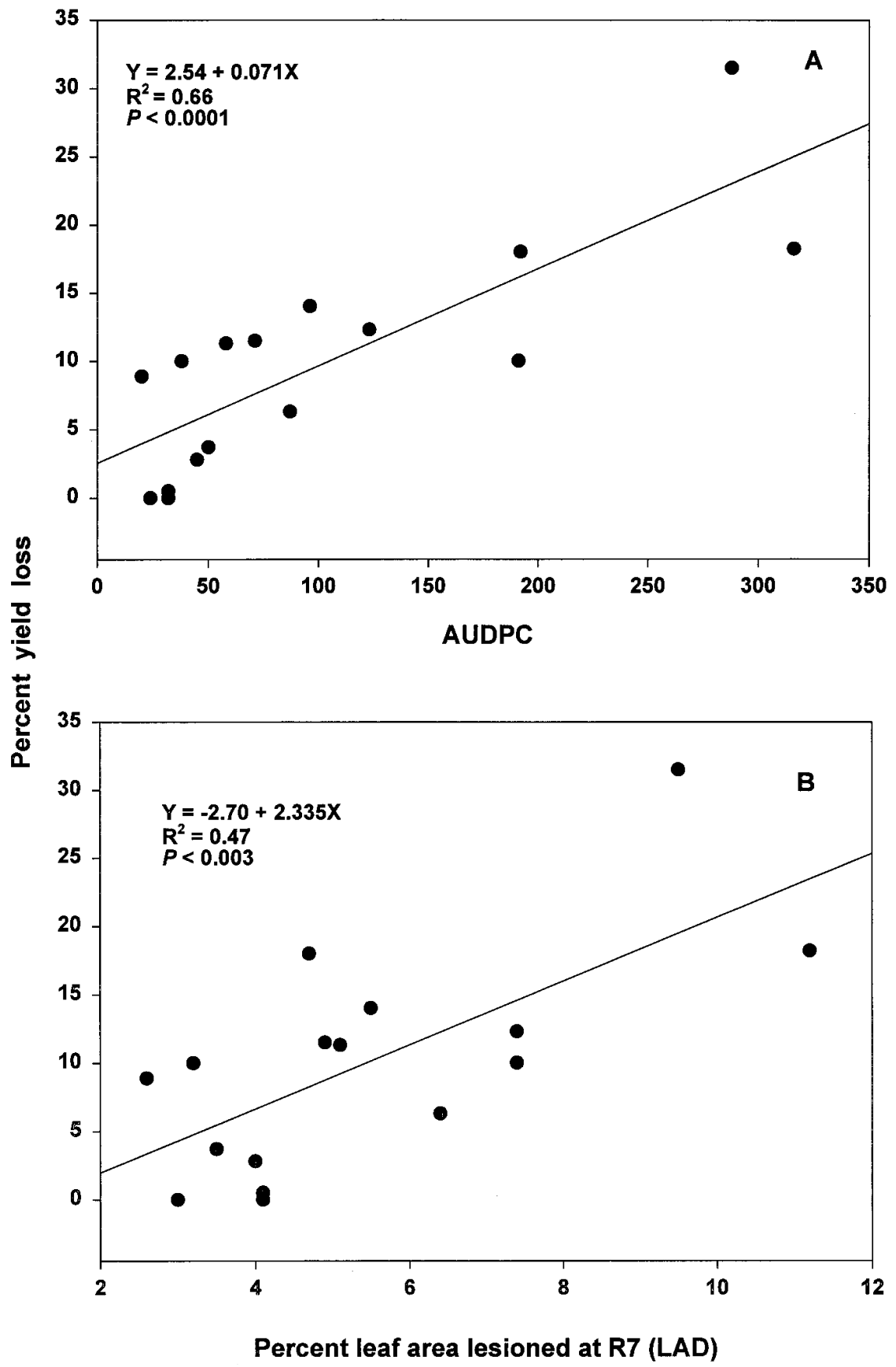

Fig. 2. Relationship between percent seed yield loss of four susceptible soybean cultivars (Colquitt, Gordon, Thomas, and Wright) compared to their resistant near-isolines, (A) area under disease progress curve (AUDPC), and (B) percent leaf area infected by frogeye leaf spot at R7 stage of development (LAD). dependent on the environmental conditions. This is in agreement with Akem and Dashiell (1), who found that the incidence of FLS on soybean was dependent on the growing conditions. All of the five experiments with $>2 \%$ FLS lesions were conducted in sites (Moganza, Louisiana; Tallassee, Alabama; and Quincy, Florida) with warm and humid growing conditions and frequent afternoon rainfall. In contrast, none of the experiments conducted on comparatively drier sites (Clemson and Blackville, South Carolina and Athens and Plains, Georgia) had FLS lesions on $>2 \%$ of total leaf area. Even though we did not keep meteorological data for all sites, it is generally true that the five experiments with $>2 \%$ FLS lesions were conducted at locations with typically more humid conditions. This is in agreement with the report of Sinclair and Backman (18).

The experiments at Athens and Midville, Georgia in 1992; at Athens, Midville, and Plains, Georgia, Clemson and Blackville, South Carolina, Fairhope, Alabama, Stoneville, Mississippi, and Quincy (early planted), Florida in 1993; and at Athens, Midville, and Plains, Georgia, Clemson, South Carolina, Fairhope, Alabama, Stoneville, Mississippi, and Quincy (early planted) and Quincy (late planted), Florida in 1994 never developed FLS lesions on $>2 \%$ of total leaf area. For these experiments, seed yield data for each pair of NILs were analyzed across environments within each year. The genotype $\times$ environment interaction was significant only for Colquitt NILs in 1994. Thus, the single degrees of freedom comparison for this pair of NILs in 1994 was tested using genotype $\times$ environment interaction mean square as the error term, while the rest of the single degrees of freedom comparisons of NIL pairs were tested using the residual as the error term.

In 1992, averaged across environments, all four $\mathrm{Rcs}_{3}$ NILs had significantly $(P \leq$ 0.01 ) higher seed yield compared to the respective susceptible lines (Table 2). Overall, the $\operatorname{Rcs}_{3}$ NILs averaged $8 \%$ higher yield than the $r c s_{3}$ lines. The seed yield of each $R c s_{3} \mathrm{NIL}$ is the mean of $14 \mathrm{BC} \mathrm{F}_{2: 3}$ lines. In 1993, averaged across the eight experiments with $<2 \%$ leaf damage, the resistant NILs did not differ in seed yield from their susceptible counterparts. In 1994, averaged over the eight experiments with $<2 \%$ leaf area damaged, the resistant NILs of Colquitt, Gordon, and Wright had significantly higher seed yield than the respective susceptible lines. Particularly, Colquitt- $\mathrm{Rcs}_{3}$ had an $18 \%$ greater seed yield than Colquitt (Table 2). The genotype $\times$ environment interaction was significant for this pair, indicating that the yield difference between the resistant and susceptible NIL was not the same across environments. The mean seed yield of the $R c s_{3}$ NIL, however, was significantly $(P \leq 0.02)$ higher than Colquitt even when tested us- 
ing the genotype $\times$ environment interaction as the error term.

The reason or reasons for the resistant NILs having higher seed yield than the susceptible lines in these environments is not clear to us. As has been mentioned earlier, FLS lesions on $<2 \%$ leaf area are not considered to have any significant effect on soybean plants. Also, the yield advantage of the resistant lines was not consistent across all environments with $<2 \%$ of the leaf area damaged. Besides the yield advantage for most of the $\operatorname{Rcs}_{3}$ NILs in two out of the three years, the data clearly demonstrate that none of the $\mathrm{RCs}_{3}$ NILs were inferior to the respective susceptible lines in seed yield in any of the three years. This indicates that the backcrossing was successful in creating $R \mathrm{Rs}_{3} \mathrm{NILs}$ without incorporating undesirable genes from the donor parent. This is not unexpected, considering that Davis, a productive cultivar, was the donor parent for $R c_{3}$.

The FLS (adjusted and non-adjusted) and seed yield data from each of the four environments with FLS lesions on $>2 \%$ of leaf area were analyzed separately as well as combined over environments. The genotype $\times$ environment interaction was significant $(P \leq 0.01)$ for both traits. Thus, we are presenting the data from each environment. In a single degrees of freedom comparison, the $\operatorname{Rcs}_{3}$ NILs had significantly $(P \leq 0.01)$ higher seed yields than the susceptible lines for all four pairs of isolines in Morganza in 1993 (average of $11 \%$ higher yield) and Tallassee in 1993 (average of 19\% higher yield; Table 3). In Quincy in 1993, all of the $R c s_{3}$ lines had higher seed yield than the corresponding susceptible lines, except for the Wright isolines. The Colquitt, Gordon, and Thomas $R \mathrm{Cs}_{3}$ NILs averaged $7 \%$ higher yield than the $\mathrm{rCs}_{3}$ lines. In Tallassee in 1994, the susceptible lines did not differ in seed yield from the corresponding $R \operatorname{cs}_{3}$ NILs, except for Colquitt (Table 3). The disease severity at Tallassee in 1994 was low, with an average of $3.6 \%$ leaf area infected at R7 stage of development, and the FLS did not damage $>2 \%$ leaf area until late in the season (25 September; Fig. 1). Under these conditions, the effect of FLS on soybean seed yield is expected to be minimal. In fact, three of the four pairs of NILs had no difference in their seed yield in this experiment. The Colquitt-Rcs 3 NIL had a $9 \%$ higher yield than Colquitt. Colquitt- $\mathrm{RCs}_{3}$ also averaged $18 \%$ higher seed yield than Colquitt in 1994 in absence of FLS infestation (Table 2).

Averaged across the four susceptible lines, Tallassee in 1993 had the highest amount of LAD (8.3\%) while Tallassee in 1994 had the lowest amount of LAD (3.6\%; Table 3). Tallassee in 1993 had the largest mean AUDPC value (248) followed by Morganza in 1993 (94). In Tallassee in
1993, Thomas had the largest AUDPC value among the four susceptible NILs, followed by Wright, and Colquitt had the smallest AUDPC. In Morganza in 1993, Colquitt had the largest AUDPC, followed by Wright, and Gordon had the smallest AUDPC (Table 3).

As mentioned earlier, a regression of percent seed yield loss of the four susceptible NILs (compared to their $R c s_{3}$ NILs) on adjusted LAD and adjusted AUDPC revealed a significant positive linear relationship (Fig. 2). However, AUDPC was a better indicator of soybean seed yield loss $\left(R^{2}=66 \%\right)$ due to FLS infestation than LAD $\left(R^{2}=47 \%\right.$; Fig. 2$)$. These results indicate that the yield loss of soybean due to FLS is not only dependent on the disease severity at the end of the growing season, but also on the cumulative disease severity over the growing season.

The average disease severity at the end of the growing season or LAD was comparable for Tallassee in $1993(8.3 \%)$ and Morganza in 1993 (6.1\%; Table 3), but the average AUDPC value at Tallassee in 1993 was two-and-a-half times higher than that at Morganza in 1993 (Table 2). This was again due to the fact that the disease developed at a much later date (15 September) at Morganza in 1993 compared to that at Tallassee in 1993 (15 August; Fig. 1). The percent yield loss for the four susceptible lines due to FLS was much higher (19\%) at Tallassee in 1993 compared to that at Morganza in $1993(11 \%)$. Thus, AUDPC values were more useful than LAD data in explaining the yield loss of the susceptible lines due to FLS. This is expected, because the yield loss from FLS is mainly due to reduced photosynthetic area and premature defoliation (1). The longer the lesions are present on the leaves, the more reduction in photosynthesis will occur, which in turn will mean less dry matter production and perhaps less seed yield. Also, early infections may result in an early defoliation of leaves.

In summary, development of FLS disease on soybean plants was dependent on growing conditions. All four of the $R c s_{3}$ NILs were resistant to FLS in all of the 23 experiments conducted at different locations across the southeastern United States. In the absence of significant FLS disease, each of the $\operatorname{Rss}_{3}$ NILs was at least equal to the respective susceptible line in its seed yield, indicating that the NILs did not carry any undesirable yield-limiting genes from the donor parent. Moreover, most of the resistant NILs had greater seed yields than the corresponding susceptible lines in the absence of significant FLS disease in two of the three years. In the presence of FLS disease, the susceptible lines suffered significant yield loss (up to $31 \%$ ) compared to their $\operatorname{Rcs}_{3}$ NILs. The effect of FLS on seed yield was dependent on cumulative disease severity over the growing season. Thus, AUDPC was more useful than percent leaf area infected at the end of the growing season in explaining the yield loss due to FLS disease.

\section{LITERATURE CITED}

1. Akem, C. N., and Dashiell, K. E. 1994. Effect of planting date on severity of frogeye leaf spot and grain yield of soybeans. Crop Prot. 13:607-610.

2. Athow, K. L., and Probst, A. H. 1952. The inheritance of resistance to frogeye leaf spot of soybeans. Phytopathology 42:660-662.

3. Athow, K. L., Probst, A. H., Kurtzman, C. P., and Laviolette, F. A. 1962. A newly identified physiological race of Cercospora sojina on soybean. Phytopathology 52:712-714.

4. Boerma, H. R., and Phillips, D. V. 1983. Genetic implications of the susceptibility of Kent soybean to Cercospora sojina. Phytopathology 73:1666-1668.

5. Dashiell, K. E., and Akem, C. N. 1991. Yield losses in soybeans from frogeye leaf spot caused by Cercospora sojina. Crop Prot. 10:465-468.

6. Fehr, W. R., and Caviness, C. E. 1977. Stages of soybean development. Iowa Coop. Ext. Serv. Spec. Rep. 80

7. Hartwig, E. E. 1990. The uniform soybean tests, Southern Region, 1989. U. S. Dep. Agric. Mimeographed Rep. U.S. Gov. Print. Office, Washington, DC.

8. Hartwig, E. E., and Edwards, Jr., C. J. 1989. The uniform soybean tests, Southern Region, 1988. U. S. Dep. Agric. Mimeographed Rep. U.S. Gov. Print. Office, Washington, DC.

9. Laviolette, F. A., Athow, K. L., Probst, A. H., Wilcox, J. R., and Abney, T. S. 1970. Effect of bacterial pustule and frogeye leaf spot on yield of Clark soybean. Crop Sci. 10:418-419.

10. Madden, L. V. 1986. Statistical analysis and comparison of disease progress curves. Pages 55-86 in: Plant Disease Epidemiology, K. J. Leonard and W. E. Fry, eds. Macmillan, New York.

11. Melchers, L. E. 1925. Diseases of cereal and forage crops in the United States in 1924. Plant Dis. Rep. Suppl. 40:186.

12. Pace, P. F., Weaver, D. B., and Ploper, L. D. 1993. Additional genes for resistance to frogeye leaf spot race 5 in soybean. Crop Sci. 33:1144-1145.

13. Phillips, D. V., and Boerma, H. R. 1981. Cercospora sojina race 5: A threat to soybeans in southeastern United States. Phytopathology 71:334-336.

14. Phillips, D. V., and Boerma, H. R. 1982. Two genes for resistance to race 5 of Cercospora sojina in soybeans. Phytopathology 72:764-766.

15. Probst, A. H., and Athow, K. L. 1958. Additional studies on the inheritance of resistance to frog-eye leaf spot of soybeans. Phytopathology 48:414-416.

16. Probst, A. H., Athow, K. L., and Laviolette, F. A. 1965. Inheritance of resistance to race 2 of Cercospora sojina in soybeans. Crop Sci. 5:332.

17. Ross, J. P. 1968. Additional physiological races of Cercospora sojina on soybeans in North Carolina. Phytopathology 58:708-709.

18. Sinclair, J. B., and Backman, P. A., eds. 1989. Frogeye leaf spot. Pages 19-21 in: Compendium of Soybean Diseases, 3rd ed. Am. Phytopathol. Soc., St Paul, MN.

19. Yorinori, J. T. 1987. Frogeye leaf spot of soybeans (Cercospora sojina Hara). Pages 1275-1283 in: World Soybean Production and Utilization Conference IV. R. Shibbles, ed. Westview Press Inc., Boulder, CO. 